\title{
Cytogenetic study of the pure Resveratrol extracted from grape skin on normal peripheral human blood lymphocytes
}

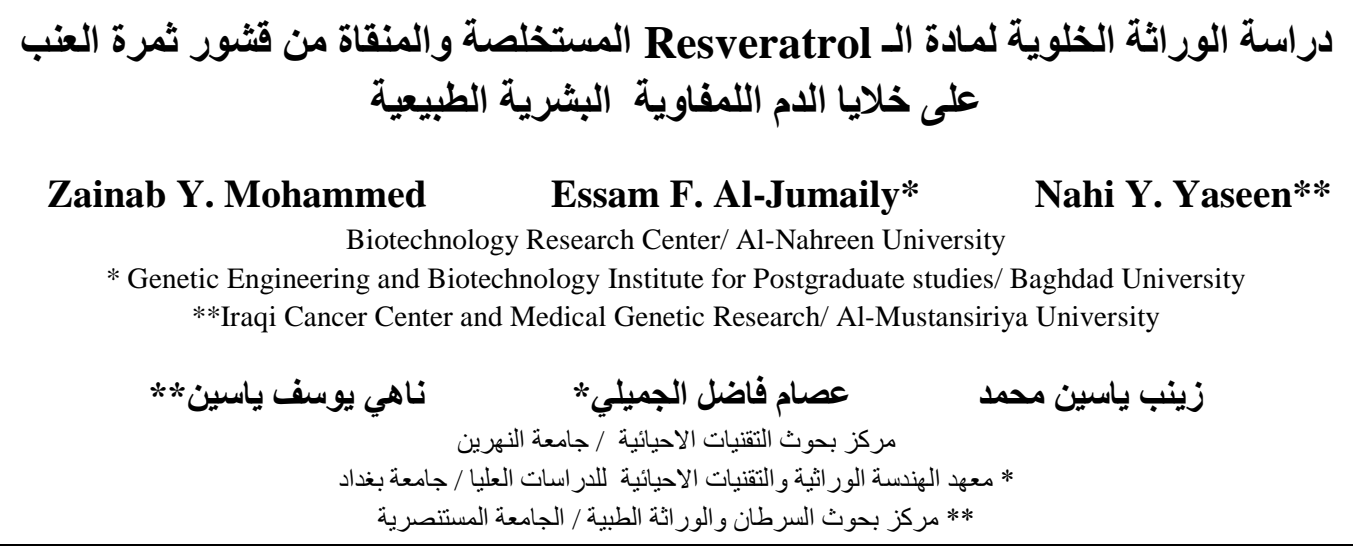

\begin{abstract}
Uhis study was conducted with the aim to extract and purify a polyphenolic compound "Resveratrol" from black grapes skin Vitis vinifera cultivated in Iraq. The pure extracted resveratrol has been employed for a cytogenetic evaluation on the normal human blood lymphocytes and revealed that the substance reduced significantly the mitotic action of the mutagen (PHA). The results of the cytogenetic study suggested that the substance appeared to have potent antimitotic and antiblastic cell formation.

هدفت هذه الدراسة الى استخلاص وتنقية المركب الفينولي Resveratrol من قثور نبات العب الاسود هitis vinifera

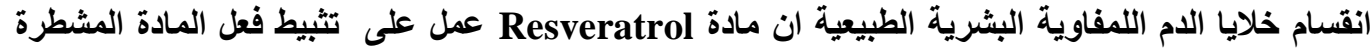

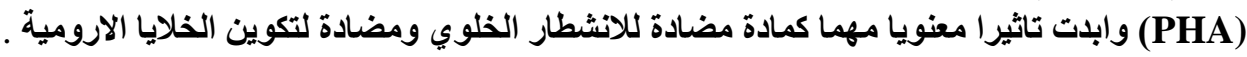

\section{Introduction}

Resveratrol (3,5,4- trihydroxystilbene) belongs to a class of polyphenolic compound called stilbene. It is a non flavonoid and non steroidal phytochemical estrogenic agent [1]. Some types of plants produce resveratrol and other stilbenes in response to stress, injury, fungal infection and ultraviolet (UV) radiation [2].

Resveratrol is a fat-soluble compound that occurs in a trans and a cis configuration. Both cis- and trans-resveratrol also occur as glucosides (bound to a glucose molecule). Resveratrol-3-O-beta-glucoside is also called piceid Figure (1). 


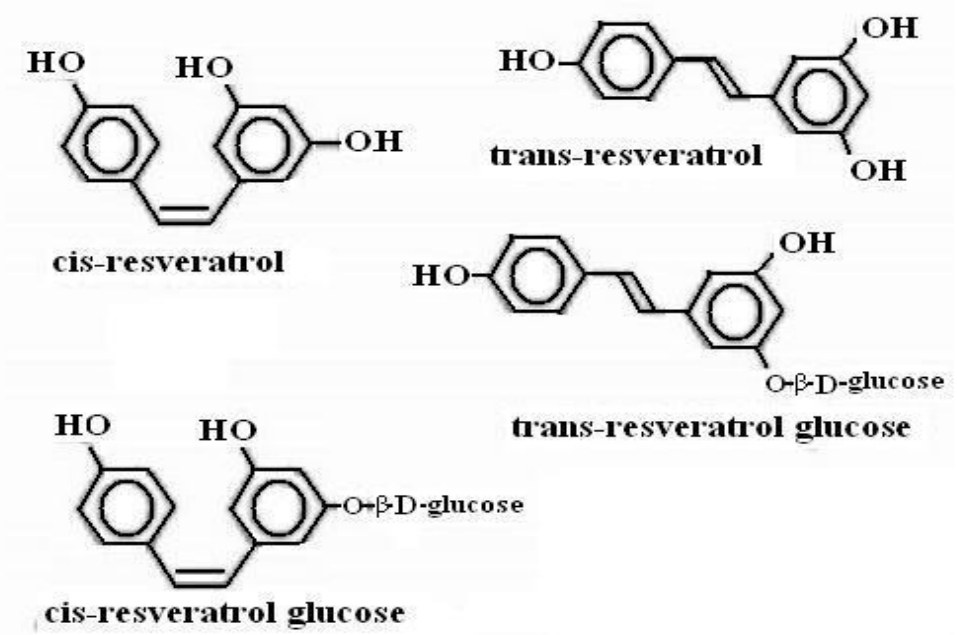

Fig. (1): Resveratrol and derivatives

It was first extracted from the root of a plant called Polygonum cuspidatum [3]. Transresveratrol is found in the skin of young unripe red grapes and it is also found in peanuts, eucalyptus, sprucem lily, mulberries and ground net [4].

Fresh grape skin contains (50-100) $\mu \mathrm{g} / \mathrm{g}$ of trans - resveratrol [3].

Scientists became interested in exploring potential health benefits of resveratrol in 1992 when its presence was first reported in red wine, leading to a speculation that resveratrol might help explain the " French Paradox" [5]. The potential for resveratrol to inhibit the development of cancer and extend lifespan in cell culture and animal models have continued to generate scientific interest [6]. The current studied on grape skin extract was aimed to the

1. Extraction and purification of the polyphenolic compound "Resveratrol" from the skin of black grape Vitis vinifera; cultivated in Iraq.

2. Evaluation of the reseveratrol as antimitotic agent among normal peripheral human blood lymphocytes.

\section{Material and Methods}

\section{Collection of samples}

Iraqi black grapes were collected from the local market and classified as Vitis vinifera by the herbarium of the Biology Department, College of Science, Baghdad University. The skin was separated from the fruit to be then kept at $4^{\circ} \mathrm{C}$, till the following steps.

Preparation and purification of the extracted pure resveratrol from the grape skin.

Preparation of grape skin extract and purification of reseveratrol was carried out according to general procedure [7] show in Figure (2). 
Fresh grape skin

(500 gram)

Continous shaking for 72 hours in cool dark place

With 2.5 litters $80 \%$ ethanol

Filtration and

Concentration to $1 / 10$ the original volume

(general test for polyphenols)

By $1 \% \mathrm{FeCl}_{3}$ solution

Acid hydrolysis

$10 \%$ HCL (cool \& filter)

$\downarrow$

Extraction with chlorofrom three times 1:1

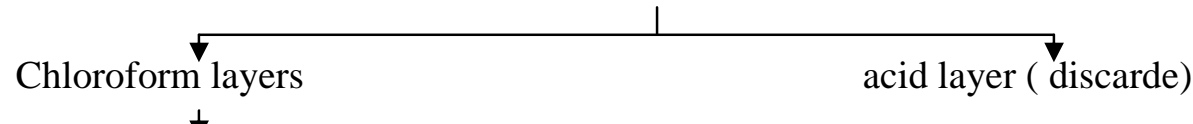

Washing with distilled water $1: 1$ (twice)

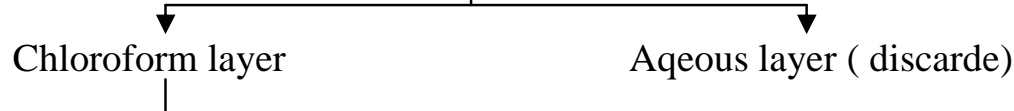

Rotary evaporation at $30^{\circ} \mathrm{C}$

Open colümn chromolography (partial purification)

Collection the (+ve elutions with $\mathrm{FeCl}_{3} 1 \%$ solution

And rotary evaporating at $30^{\circ} \mathrm{C}$ to dryness

T.L.C detection

Partion separation

Ethyl acetate: $\mathrm{H}_{2} \mathrm{O}$

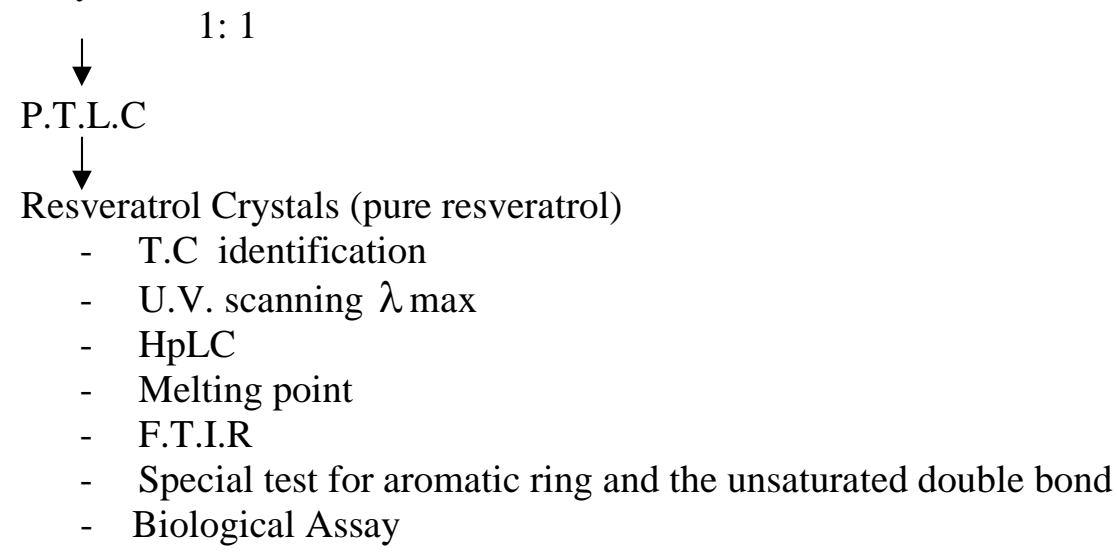

Fig (2): Steps for Resveratrol Extraction, Isolation and Purification [7] 
Cytogenetic study of the pure extracted resveratrol on normal human circulating blood lymphocytes according to Iraqi Center for Cancer and Medical Genetic Research (ICCMGR).

The following solution should be prepared [8]:

a) Colchicine solution was prepared by dissolving $1.0 \mathrm{mg}$ of colchicine in a $10 \mathrm{ml}$ D.W.; filtration was then performed stored at $4{ }^{\circ} \mathrm{C}$.

b) Hypotonic solution $(0.075 \mathrm{M} \mathrm{KCl})$ was done by dissolving $1.1175 \mathrm{~g}$ of $\mathrm{KCl}$ powder in $200 \mathrm{ml} \mathrm{D}$. W.; the stock solution was stored at $4^{\circ} \mathrm{C}$.

c) The fixative employed for cytogenesis studies was a freshly made mixture of absolute methanol and glacial acetic acid in the ratio 3:1 (v/v)

d) Sorenson's buffer was made by dissolving $9.47 \mathrm{~g}$ of $\mathrm{KH}_{2} \mathrm{PO}_{4}$ into one Liter of D.W., and then the stock solution was stored at the room temperature until use.

e) Giemsa stain in which a stock solution was prepared by dissolving $2 \mathrm{~g}$ of Giemsa stain powder in a $100 \mathrm{ml}$ of methanol then stirred constantly using a magnetic stirrer at room temperature for two hours. The solution was filtered by a filter paper (Wattman No.1) and stored in a dark tight bottle, on staining (1) $\mathrm{ml}$ of the stock solution was added to (4) $\mathrm{ml}$ of Sorenson's buffer.

f) Phytohaemagglutinin (PHA): It was supplied as a liquid by Iraqi Cancer Center and Medical Genetic Research (ICCMGR).

g) Blood collection: Blood was taken from normal adult humans by puncturing using a disposable syringe (5) $\mathrm{ml}$ of blood was transferred into heparinzed tubes.

\section{Blood culture with plant extracts:}

a) Half $\mathrm{ml}$ of peripheral blood was added to all test tubes containing $5 \mathrm{ml}$ of culture media (with $20 \%$ fetal calf serum).

b) Phytohaemagglutinin (0.3) $\mathrm{ml}$ was added to all test tubes, then the following concentrations $(50,100,150 \mu \mathrm{g} / \mathrm{ml})$ of the prepared pure resveratrol solution were added to each tube. (Two replicates for each concentration) and three test tubes free of plant extract as positive control and another three test tubes free of plant extract and PHA as negative control.

c) All test tubes were returned to the $\mathrm{CO}_{2}$-incubator for $70 \mathrm{hrs}$ and gently shaken each $12 \mathrm{hrs}$ one time at least.

\section{Harvesting}

After $70 \mathrm{hrs}$ of incubation, $0.1 \mathrm{ml}$ of fresh colchicine solution was added to each test tube and re- incubated to complete $72 \mathrm{hrs}$.

a) Samples were centrifuged for 10 minutes at $1500 \mathrm{rpm}$.

b) Supernatant was withdrawn by Pasteur pipette and about $0.5 \mathrm{ml}$ of supernatant above the precipitated cells in the test tube was left.

c) Precipitates were mixed very well by the vortex mixer, and then $5-10 \mathrm{ml}$ of warmed $37^{\circ} \mathrm{C}$ Potassium chloride $(0.075 \mathrm{M})$ was added gradually and gently with mixing.

d) Samples were incubated in the shaker water bath for 20 minutes at $37^{\circ} \mathrm{C}$

e) Samples were centrifuged for 10 minutes at $1500 \mathrm{rpm}$, and then thesupernatant discarded. 
f) Few drops of the freshly made fixative (methanol and glacial acetic acid 3:1 v/v) were added drop wise with gently mixing until reaching $5 \mathrm{ml}$; later on centrifugation performed for 10 minutes at $1500 \mathrm{rpm}$ then fixative decanted off and the process repeated for 2-3 times. At the final change, the cells re-suspended in a $3 \mathrm{ml}$ of freshly made fixative and stored at $-20^{\circ} \mathrm{C}$ till the next step.

\section{Slide preparation}

The procedure was followed according to ICCMGR protocol. The cell suspension was removed from freezer and centrifuged at $1500 \mathrm{rpm}$ for 10 minutes. The supernatant was decanted off and the cells re-suspended in appropriate amount to make thinly cloudy suspension. By using Pasteur pipette, 3-4 drops of cells suspension were dropped evenly from appropriate distance $30 \mathrm{~cm}$ onto wet, chilled, grease-free slides and allowed to dry at room temperature.

\section{Staining}

The slides were stained using freshly made [Giemsa stain stock solution and Sorenson's buffer 1:4 v/v ] which was applied for two minutes, then rapidly washed with Sorenson's buffer, after that the excess solution was removed from slides by fiber free paper. Microscopic examination under low magnification using 10X objective lens was performed to determine mitotic index (MI \%) and blast index (BI \%)

MI \% analysis: The MI \% was determined as a ratio of the mitotic cells to the cells in interphase in 1000 calculated cells.

M.I. $\%=($ No. of Dividing cells / No. of dividing cells + No. of non -dividing cells $) \mathrm{x}$ $100[9]$.

BI \% analysis: The BI\% was determined as a ratio of the cells in blast form to the other cells in 1000 calculated cells [10].

\section{Statistical analysis}

The SAS (2001) program was used to study the effects of treatments in different trails. The least significant difference (LSD) test was used to signify a comparison between the means.

\section{Results and Discussion}

\section{Extraction and Purification of Resveratrol}

The yield of the pure crystals is about " $35 \mathrm{mg}$ " for the $500 \mathrm{~g}$ grape skin used; there may be some lost during processing of extraction, since the naturally occurring transresveratrol easily oxidized and converted to the cis - configuration by day or UV light and with the presence of heat, heavy metals and atmospheric oxygen $[1 ; 11]$

The fresh skin of black grapes (Vitis viniferous) is rich with a non- flavonoid polyphenol, resveratrol [12] and each gram of fresh grape skin contains (50-100) microgram of pure resveratrol [13]. In the present study, each gram of fresh black grape skin yielded approximately $70 \mathrm{mg}$ of pure resveratrol [14].

\section{Cytogenetic Study on normal Lymphocyte Blood Cell Mitotic Index (M.I.\%)}

The results of pure extracted resveratrol in concentrations $[50,100,150] \mu \mathrm{g} / \mathrm{ml}$ on the mitotic index of normal lymphocyte exposed to mitogenic action of PHA (phytohemagglutinin) in comparison with the negative control group ( lymphocyte 
only without PHA treatment or extract ) and positive control (lymphocyte blood cells with PHA treatment only) was shown in Table (1).

The negative control representing the normal human blood lymphocyte had not any mitogenic activity $(0 \%)$ since the cells were not exposed to a mitogen action of PHA. The positive control showed a mitotic index of 3.5\%. The mitotic index values of the treated group with $50 \mu \mathrm{g} / \mathrm{ml}$ revealed a highly significant decrease $(1.15 \% \pm 0.05 \%)$, while the treated group with $100 \mu \mathrm{g} / \mathrm{ml}$ also gave a small but none significant mitotic index $(2.5 \% \pm 0.5 \%)$. The exposure of lymphocyte to $150 \mu \mathrm{g} / \mathrm{ml}$ resveratrol pure extract turned mitotic index to a level identical to that of the (50) $\mu \mathrm{g} / \mathrm{ml}$.

The results revealed that the pure resveratrol antagonized the mitotic action of PHA, and acted as anti-mitotic agent even from the lowest concentration $50 \mu \mathrm{g} / \mathrm{ml} \mathrm{Fig} \mathrm{(3).}$ The higher does affected the mitotic process in the normal lymphocyte but the chromosomal changes might be intacted. Grape skin extracted at doses $(5 \mathrm{mg} / \mathrm{mouse})$ up to $(100 \mathrm{mg} / \mathrm{mouse}$ ) caused no increase in the cell division (MI\%) of the normal mouse bone marrow cells administrated with the grape skin extract only. While in the tumor mice induced with mytomycin-C (MMC), the grape skin extract reduced (MI \%) significantly in a dose dependent manner [15].

\section{Blast Index (B.I. \%)}

Similar results obtained with blast cells formation Table (1). The PHA treated control positive group showed a high percentage of blast cells $37 \%$ while the negative control group (untreated with PHA) revealed a blast formation $(1 \% \pm 0.25 \%)$. All different concentrations of pure extracted resveratrol [50,100 and 150$] \mu \mathrm{g} / \mathrm{ml}$ no significantly results in blast index $(14 \%, 16 \%$ and $13.25 \% \pm 3 \%, 2.15 \%$ and $2.55 \%$ respectively) compared to PHA effect, but no significant differences were observed among the three different concentrations of the extract.

The comparison between the positive control and all extracted resveratrol treated groups showed a significant reduction in blast index value, leading to an indication of a potent antiblastic cell formation effect of resveratrol Figure (3).

$[15,16]$ investigations about grape skin extract in treating acute myeloid leukemia (AML) cells concluded that the effect of the extract was irreversible with cytotoxic effect on (AML) blast cells and plasma cytoma cell line, with low or non cytotoxicity on normal human lymphocytes and normal mouse embryo fibroblast without inducing morphological differentiation in an in vitro AML blast cells . The extract showed anti leukemic cell reproductively and chromosomal abnormalities in an in vitro dose dependent manner.

Resveratrol in a number of in vitro studies demonstrated the antiproliferative effects in various leukemic cell lines (U937), inducing apoptosis through the $\mathrm{CD}_{95}-\mathrm{CDL}_{95}$ $[17,18]$. Resveratrol at low concentrations $(4-8 \mu \mathrm{M})$ was shown to inhibit apoptosis in human leukemia cells via nicotinamide adinine dinucleotide hydrogen phosphate (NADPH) oxidase-dependent elevation of intracellular superoxide that blocks mitochondrial hydrogen peroxide production, thus resulting in a cellular environment not susceptible to apoptosis induction [19]. 
Table (1): Cytogenetic study of the extracted pure resveratrol on normal lymphocyte blood cell

\begin{tabular}{|c|c|c|}
\hline Concentration & \multicolumn{2}{|c|}{ Mean \pm SE } \\
\hline$\mu \mathrm{g} / \mathrm{ml}$ & M.I. \% & B.I. \% \\
\hline 50 & $1.15 \pm 0.05^{c}$ & $14.60 \pm 3.00^{b}$ \\
\hline 100 & $2.50 \pm 0.50^{a b}$ & $16.65 \pm 2.15^{b}$ \\
\hline 150 & $1.10 \pm 0.00^{c}$ & $13.25 \pm 2.55^{b}$ \\
\hline $\mathrm{C}+\mathrm{ve}$ & $3.50 \pm 0.50^{a}$ & $37.00 \pm 7.00^{a}$ \\
\hline $\mathrm{C}-\mathrm{ve}$ & $0.00 \pm 0.00^{d}$ & $1.00 \pm 0.25^{c}$ \\
\hline LSD & $1.0014 * *$ & $11.887 * *$ \\
\hline Probability level & 0.0015 & 0.0043 \\
\hline
\end{tabular}

*** $(\mathbf{P}<\mathbf{0 . 0 1})$.

The means within columns with different letters are significantly different at $\mathbf{P}<0.01$.

MI\% = mitotic index

BI\% = Blast index

\section{References}

1. Budavari, S. 1996. The Merck Index, $12^{\text {th }}$ ed. Merck \& Co., Inc. Whitehouse Station, N.

2. Tomas- Barberan, F.A. and Robins, R. J. 1997. Phytochemistry of fruit and vegetables. Clarendon press- Oxford. New York.

3. Hendler, S.S. and Rorvik, D. 2001. Resveratrol In: PDR for Nutritional Supplements. Medical Economics, Thomson Healthcare, Montrale.

4. Karen. E. and Hancke, M.S. 2002. Review of Toxicological literature. National Institute of Enviromental Health Science. North Carolina.

5. Pussa T., Floren, J., Huldhepp, P., and Raal, A. 2006. Survery of grape wine vitis vinefera sternpoly phenols by liquid chroma tography - Diode array detection tandem mass, spectrometry. J. Agric. Foodchem, 54: 7488-7494.

6. Howitz, K.T., Bitterman, K.J., Cohen, H.Y., Lamming, D.W., Lavu, S., Wood, J.G., Zipkin, R.E., Chung, P., Kisielewski, A., Zhang, L.L., Scherer, B. and Sinclair, D.A. 2003. Small molecule activators of sirtuins extend Saccharomyces cerevisiae lifespan. Nature. 11:191-196.

7. Harborne, J.B., 1984. Phytochemical Methods. Chapman and Hall. London.

8. Yaseen, N. Y., Humadi, A.A., Tawfiq, M.S. and Estivan, A.G. 1998. Cytogenetic studies on patients with chronic myclocytic leukemia. The Medical Journal of Tikrit Univ. 4: 5-9.

9. Shubber,E.K. and Al-Alak, B.A. 1986. Spontaneous chromosomal aberration and SCE in human lymphocytes; effect of culture conditions nucleus. 29: 92-98.

10. Shubber,E.K., Amin, B.H. and El-Adhami, B.H. 1998. Cytogenetic effect of copper containing intrauterine contraceptive device (IUCD) on blood lumphocytes. Mutat. Res. 266: 1-7.

11. Bavaresco,L. 2003. Role of viticultural factors on stilbene concentrations of grape and wine. Drugs Exp. Clin. Res. 29: 181-187.

12. Al-Malikey, Z.S.L. 2004. Studing content of some local grapes varieties vitis vinifera L. from phenolic compounds. Ph.D. thesis, College of Agriculture Univ. of Baghdad, Iraq. 
13. Baliga,M.S. , Meleth,S. and Katiyar,S.K. 2006. Chemoprevention of photocarcinogenesis by selected dietary botanicals. Photochem. Photobiol. Sci. 5: 243- 253.

14. Zainab Y.M., Essam F.A.J. and Ali. O. A.S. 2009. Extraction and purification of resveratrol from grape skin fruit vitis vinifera, Iraqi J. of Biotechnology, 8 (2): 2009.

15. Al-Duliemy, D.W.A. 2005. Anticlastogenicity and anti leukemic cell potencies of alcoholic extracts from grape skin (vitis vinifera). M.Sc. thesis. Genetic Engineering and Biotechnology Institute. Baghdad University.

16. Al-Tememi, M.A.S. 2006, In vitro study of the effect of Arsenic Trioxide and vitis vinifera (Grape) skin extracts on proliferation, Differentiation and Apoptosis of Mycoblast cells. M.Sc. College of Science, University of Al-Nahrin - Baghdad.

17. Gautam,S.C., Xu,Y.X., Dumaguin, M. and Chapman, R.A.2000. Resveratrol selectively inhibits leukemia cells aprospective agentfor exvivo bone marrow punging. Bone Marrow Transplant. 25: 639-645.

18. Gao, D., Zhang, X., Tiang, X., Peng, Y. and Song, L. 2002. Resveratrol reduces the elevated level of MMp-9 induced by cerebral ischemia - reperfusion Institute of Neurosurger. China.

19. Ahmed,K.A., Clement, M.V., Hanif, I.M. and Pervaiz,S. 2004. Resveratrol inhibits drug- induced apoptosis in human leukemia cells by creating an intracellular miliea nonpermissive for death execution. Cancer Res. 64: 1452-1459. 